\title{
Multilevel orthopaedic surgery in children with spastic cerebral palsy
}

\author{
D.A. Popkov ${ }^{1}$, G.M. Chibirov' ${ }^{1}$ V.V. Kozhevnikov ${ }^{2}$, N.S. Gvozdev ${ }^{1}$
}

${ }^{1}$ Ilizarov National Medical Research Centre for Traumatology and Orthopedics, Kurgan, Russian Federation

${ }^{2}$ Federal Center for Traumatology, Orthopedics and Endoprosthetics, Barnaul, Russian Federation

\begin{abstract}
Introduction The purpose of the article was to review the modern literature on the role of multilevel single-stage interventions in the surgery of secondary orthopaedic complications in children with cerebral palsy. Material and methods The review was done using the databases of the current sources of scientific information including PubMed, Scopus, ResearchGate, RSCI and Elsevier, Springer publishing products. A report made for the first educational meeting of the European Pediatric Orthopaedic Society held in Russia at the Ilizarov Center in 2021 was used for the contribution. Results and discussion The article discusses terminology, indications, particular techniques and early postoperative period, long-term outcomes of multilevel orthopaedic interventions and aspects of iatrogenic orthopaedic conditions in children with cerebral palsy. Conclusion Multilevel intervention is the surgical procedure of choice for the correction of secondary orthopaedic complications in patients with cerebral palsy. The success of the surgery would depend on adequately identified indications and quantitative values of the correction to be performed on the basis of 3D gait analysis, the compliance with specific technical requirements for the procedure and an early rehabilitation program. The strategy of multilevel interventions suggests the greatest possible reduction in the number of orthopaedic surgeries and can be considered successful if the patient undergoes a maximum of two multilevel reconstructive interventions in the childhood. Keywords: cerebral palsy, single-event multilevel orthopaedic surgery
\end{abstract}

\section{INTRODUCTION}

Cerebral palsy $(\mathrm{CP})$ is the most common cause of motor disorders in childhood [1]. The incidence of $\mathrm{CP}$ is 3.6 per 1000 children in the United States [1], 2.4 cases per 1000 children in Sweden [2], which is close to the data for Russia, more than 1500 new cases are registered annually in France [3], and more than $240000 \mathrm{CP}$ patients below the age of 20 live in Europe [4]. Bilateral and unilateral spastic, dystonic
$\mathrm{CP}$ are most common among other forms of the condition accounting for $83-85 \%[3,5]$. Patients with these $\mathrm{CP}$ types are likely to develop orthopaedic complications that require surgical correction [6-9]. The purpose of the article was to review the current literature on the role of multilevel single event interventions in the surgery of secondary orthopaedic complications in children with CP.

\section{MATERIAL AND METHODS}

The review was done using the databases of the current sources of scientific information including PubMed, Scopus, ResearchGate, RSCI and Elsevier, Springer publishing products. A report made for the first educational meeting of the European Pediatric Orthopaedic Society held in Russia in the Ilizarov Center in 2021 was used for the contribution describing different aspects of multilevel interventions.

\section{RESULTS AND DISCUSSION}

\section{Definition}

Single-event multilevel orthopaedic surgery (SEMLS) is defined as corrections of soft tissue and/ or bony deformities at a minimum of two anatomical levels during a single operative event. The advantage of a SEMLS procedure is that only one hospital admission and recovery period are needed for multiple interventions [10-12]. In addition to the medical benefits, the approach facilitates reduced burden of treatment events on the social life of the patient and the family, and also adds to economic advantages for the healthcare system $[6,7,13-15]$. Large scale surgical intervention can be performed sequentially on two limbs with an interval of 2-4 weeks inbetween during one hospital admission but with a single rehabilitation period that helps maintain the SEMLS principles [16-18]. The advantages of a multi-level approach compared to staged isolated operations in children with cerebral palsy became obvious and were recognized in the 80-90s of the twentieth century [19-21]. Fabry et al. [22] are convinced that 3D gait analysis is useful in evaluating these patients and improves the results of operative treatment, and they have since changed their approach toward multilevel simultaneous corrections. 
Three-dimensional gait analysis, the role in diagnosis and planning SEMLS

Three-dimensional gait analysis allows synchronous evaluation of the kinematic, kinetic and electroneuromyographic parameters of the gait in $\mathrm{CP}$ patients GMFCS levels I-III [23-25]. The basic works on gait analysis identified the main pathological patterns of the gait and movements for individual joints that classified walking disorders and facilitated planning of surgical interventions differentiating equinus gait, jump gait, apparent equinus gait, crouch gait, asymmetric gait, stiff knee gait [8, 23-26].

The accuracy and informative value of the gait analysis is superior to physical examination in identifying pathological components of movements and the causes. Authors report different coincidence rate of clinical and computerized gait data with the percentage of 66$100 \%$ [25], 50-68 \% [27], $22 \%$ [28], 59-90\% [29], $71.7 \%$ [30]. Gait deviations identified by 3D analysis failed to be identified with clinical evaluation in $19.9 \%$ of cases, and gait analysis allowed for ruling out false positive clinical symptoms in $8.4 \%$ of cases [30].

Moissenet $\mathrm{M}$ et al. [31] overviewed the management of patients with gait deviations including 3D gait analysis:

1) identifying gait deviations;

2) establishing the relationship of different types of medical data, such as from clinical gait analysis, physical examination or imaging results;

3) choosing the best surgical approach.

The role of 3D analysis implies the measurement of kinematic and spatiotemporal parameters assessing the result of treatment and monitoring the evolution of the patient's capacity to walk after multilevel interventions [11, 32-34].

The authors report general goals and principles of planning multilevel interventions [11, 12, 35-41]. Orthopaedic multilevel single-event interventions are goal-oriented, and planning should be based on the objective analysis of movements and the gait. It is important to understand that surgical orthopaedic intervention does not change the level of GMFCS, but it allows for elimination of secondary orthopaedic complications that interfere with the ambulation potential to be realized by a particular patient.

The fundamental goals of SEMLS are:

- correction of deformities to improve the biomechanics of ambulation including torsion (shoulder lever dysfunction);

- elimination of joint contractures to improve daily motor activity and increase functional capabilities;

- reduction of energy expenditure associated with biomechanical disorders;
- prevention or reduction of pain caused by early arthrosis;

- reduction/elimination of problems with the use of shoes and orthosis.

General principles of surgical multilevel technique

The multilevel intervention suggests producing passive movements in the joints of the operated limb with the use of adjustable orthosis and progressive axial loading 2-3 weeks postoperatively initiating early rehabilitation [42]. It is recommended to lengthen muscles through aponeurotomies and produce tendon transfer with anchors rather than suture tendons [43-45]. In addition to that, the elongation of the muscles through the aponeurotic portion without increase in the tendon portion allows for maintaining the contractile capacity and muscle strength of the tissue along with an increased amplitude of passive movements [46, 47]. With correction osteotomies, bone reconstruction procedures, arthrodeses of the feet implants and fixation components made of titanium alloys are practical for primary bone stability to ensure early progressive functional loading on the limbs and a rapid transition from temporary immobilization with a plaster cast to adjustable orthoses [48-54].

The approach suggests reduction of blood loss due to the use of squeezing and hemostatic tourniquets, reduction of the operation time (employing two surgical teams), accurate recording of the angles achieved for passive movements, early postoperative rehabilitation and measures to prevent trophic disorders of soft tissues $[16,18]$.

\section{Early rehabilitation following SEMLS}

Early passive and active joint mobilization, verticalization of patients with full axial loading, replacing plaster casts with adjustable orthosis after three to four postoperative weeks post surgery are generally recognized principles of rehabilitation after multi-level interventions [11, 47, 55-58]. Pain is common in the early postoperative period and after the removal of immobilization [59]. Botulinum therapy is indicated postoperatively for pain relief in the mobilized muscles [60]. Rehabilitation suggests getting involved into activities of daily living and school classes from the first postoperative months [61]. Patients can regain initial spatiotemporal parameters of the gait or improve them at one year post surgery [61] with overall improvement in motor functions and the quality of life seen within the second year after surgery [62].

\section{Outcomes of SEMLS at a long term}

Evaluation of the effectiveness of multilevel interventions at a long term period remains an important issue. The results of treatment evaluated at 1-2 years after surgery and 3-5 years after surgery 
provide a balanced representation of the outcomes at a short and medium term [10]. Harvey et al. [63] reported no change in the GMFCS class after SEMLS but steady improvements in the scores on the Functional Mobility Scale. The results of treatment followed up for 10 years and over featured improved kinematic and spatiotemporal parameters. Motor disorders were not seen to slowly deteriorate in the crouch gait patients, but additional interventions were required in $61.5 \%$ of cases during 10 years of followup to maintain the result primarily achieved [34].

Haumont et al. [64] reported a sample group of 97 children with spastic $\mathrm{CP}$ who walked with a flexed-knee gait (crouch gait pattern or its debut) and underwent SEMLS, showed an overall improvement in gait at 10 years follow-up. In this study, $69 \%$ of children underwent one or two surgical events including initial surgery and $31 \%$ had undergone three or more in a 10 year period, and $68 \%$ were considered as candidates for additional surgical intervention at the age of 18 . Dreher T. et al. [65] reported a multi-center study including 331 children with bilateral spastic $\mathrm{CP}$ evaluated at long term (9.1 years) follow-up, and 177 (76.6\%) children could maintain their improvement in GPS (Gait Profile Score). Thirty-nine per cent of children required additional surgery during follow-up.

All the authors of the above series with a follow-up period of 9 years or more consider the term SEMLS to be changed to the more realistic term 'multilevel surgery' (MLS), because more than a third of cases require additional interventions over a course of longterm follow-up to maintain the result achieved. No more than two reconstructive interventions can be produced for $\mathrm{CP}$ patients before skeletal maturity for the successful planning and surgical treatment [64]. Maintaining the spatiotemporal and kinematic parameters of gait in the long-term period is accompanied by higher quality of life which correlate with the GMFCS level $[64,66]$.

Iatrogenic complications, procedures to be not recommended

In addition to the natural development of the crouch gait pattern, an iatrogenic crouch gait pattern can develop after unreasonable fibromyotomies and isolated Achilles lengthening performed at an early age $[67,68]$. The subsequent inevitable weakening of the tibial triceps can lead to a lost function of the soleus muscle and the eccentric contraction, absorption of the kinetic energy of the supporting limb and pathological knee flexion in the supporting phase [25, 69-72]. As mentioned above, only an aponeurotomy of the gastrocnemius muscle allows for maintaining the pushing force during plantar flexion of the foot and prevents the development of triceps weakness [46]. Gatamov O.I. et al. reported [73] the adverse event occurring in the group of iatrogenic gait disorders at an earlier age as compared with patients who develop the condition as a natural course. Iatrogenic crouch gait is typical for GMFCS level II patients, while GMFCS level III is common for patients without previous surgical treatment [73]. In addition to that, there is a negative effect from early interventions performed for plantar flexors (Ulzibat fibromyotomy, open Achilles lengthening in children with spastic diplegia [67, 72, $74,75])$ that can result in the early development of the pathological crouch gait pattern in children with $\mathrm{CP}$ GMFCS levels I and II and without torsion deformities.

There is a risk of trauma and premature closure of the anterior portion of the physis of the proximal tibia and associated genu recurvatum deformity when the patella is brought down, the patellar tendon mobilized (in isolation or with a fragment of the underlying bone), and the periosteum is fixed with circlage and Kirschner wires in a traumatic manner [76]. Hachache et al. [77] evaluated the effectiveness and safety of percutaneous proximal gracilis tenotomy in children with $\mathrm{CP}$ and identified iatrogenic lesions including an injury of the anterior branch of the obturator nerve, considerable bleeding with hematoma formation considering the deep location of the proximal tendon of the $\mathrm{m}$. gracilis in the soft tissues. Percutaneous medial hamstring myofascial lengthening is often associated with an abusive injury of the muscle itself as compared to open procedure [78]. Therefore, percutaneous lengthening of the retracted muscles is highly discouraged at the above sites.

\section{CONCLUSION}

Multilevel intervention is the surgical procedure of choice for the correction of secondary orthopaedic complications in patients with cerebral palsy who can improve the ambulation capacity and the quality of life. The success of the surgery would depend on adequately identified indications and quantitative values of the correction to be performed on the basis of $3 \mathrm{D}$ gait analysis, the compliance with specific technical requirements for the procedure and an early rehabilitation program. The strategy of multilevel interventions suggests the greatest possible reduction in the number of orthopaedic surgeries and can be considered successful if the patient undergoes a maximum of two multilevel reconstructive interventions in the childhood. 


\section{REFERENCES}

1. Damiano D.L., Alter K.E., Chambers H. New Clinical and Research Trends in Lower Extremity Management for Ambulatory Children with cerebral Palsy. Phys. Med. Rehabil. Clin. N. Am., 2009, vol. 20, no. 3, pp. 469-491. DOI: 10.1016/j.pmr.2009.04.005.

2. Westbom L., Hagglund G., Nordmark E. Cerebral palsy in a total population of 4-11 year olds in southern Sweden. Prevalence and distribution according to different CP classification systems. BMC Pediatr., 2007, vol. 7, pp. 41. DOI: 10.1186/1471-2431-7-41.

3. Viehweger E., Robitail S., Rohon M.A., Jacquemier M., Jouve J.L., Bollini G., Simeoni M.C. Measuring quality of life in cerebral palsy children. Ann. Readapt. Med. Phys., 2008, vol. 51, no. 2, pp. 119-137. DOI: 10.1016/j.annrmp.2007.12.002.

4. Krägeloh-Mann I. Klassifikation, Epidemiologie, Pathogenese und Klinik. In: Heinen F., Bartens W. Das Kind und die Spastik. Erkenntnisse der Evidenced-based Medicine zur Cerebralparese [The child and the spasticity. Findings of evidenced-based medicine on cerebral palsy]. Bern, Verlag Hans Huber, 2001, pp. 37-48. (in German)

5. Hagberg B., Hagberg G. The origins of cerebral palsy. In: David T.J., editor. Recent advances in Paediatrics. XI Ed. Edinburgh: Churchill Livingstone, 1993, pp. 67-83.

6. Abel M.F., Damiano D.L., Pannunzio M., Bush J. Muscle-tendon surgery in diplegic cerebral palsy: functional and mechanical changes. J. Pediatr. Orthop., 1999, vol. 19, no. 3, pp. 366-375.

7. Wren T.A., Rethlefsen S., Kay R.M. Prevalence of specific gait abnormalities in children with cerebral palsy: influence of cerebral palsy subtype, age, and previous surgery. J. Pediatr. Orthop., 2005, vol. 25, no. 1, pp. 79-83. DOI: 10.1097/00004694-200501000-00018.

8. Ounpuu S., Muik E., Davis R.B. $3^{\text {rd }}$, Gage J.R., DeLuca P.A. Rectus femoris surgery in children with cerebral palsy. Part I: The effect of rectus femoris transfert location on the knee motion. J. Pediatr. Orthop., 1993, vol. 13, no. 3, pp. 325-330. DOI: 10.1097/01241398-199305000-00010.

9. Saraph V., Zwick E.B., Zwick G., Steinwender C., Steinwender G., Linhart W. Multilevel surgery in spastic diplegia: evaluation by physical examination and gait analysis in 25 children. J. Pediatr. Orthop., 2002, vol. 22, no. 2, pp. 150-157.

10. Lamberts R.P., Burger M., du Toit J., Langerak N.G. A Systematic Review of the Effects of Single-Event Multilevel Surgery on Gait Parameters in Children with Spastic Cerebral Palsy. PLoS One, 2016, vol. 11, no. 10, p. e0164686. DOI: 10.1371/journal.pone.0164686.

11. McGinley J.L., Dobson F., Ganeshalingam R., Shore B.J., Rutz E., Graham H.K. Single-event multilevel surgery for children with cerebral palsy: a systematic review. Dev. Med. Child. Neurol., 2012, vol. 54, no. 2, pp. 117-128. DOI: 10.1111/j.1469-8749.2011.04143.x.

12. Popkov D., editor. Understanding in Children with Cerebral Palsy: Orthopedic Problems. Nova Medicine and Health, 2020.

13. Stout J.L., Gage J.R., Schwartz M.H., Novacheck T.F. Distal femoral extension osteotomy and patellar tendon advancement to treat persistent crouch gait in cerebral palsy. J. Bone Joint Surg. Am., 2008, vol. 90, no. 11, pp. 2470-2484. DOI: 10.2106/JBJS.G.00327.

14. Rodda J.M., Graham H.K., Nattrass G.R., Galea M.P., Baker R., Wolfe R. Correction of severe crouch gait in patients with spastic diplegia with use of multilevel orthopaedic surgery. J. Bone Joint Surg. Am., 2006, vol. 88, no. 12, pp. 2653-2664. DOI: 10.2106/JBJS.E.00993.

15. Gubin A.V., Ovchinnikov E.N., Goncharuk E.V., Vasileva N.I., Popkov D.A. Ekonomicheskie aspekty mnogourovnevykh ortopedicheskikh operatsii u patsientov s detskim tserebralnym paralichom [Economical aspects of multilevel orthopedic surgeries in patients with children cerebral palsy]. Problemy Sotsialnoi Gigieny, Zdravookhraneniia i Istorii Meditsiny, 2020, vol. 28, special issue, pp. 716-722. (in Russian)

16. Cottalorda J., Bourelle S., Chotel F., Dohin B., Penneçot G.-F. L'infirme moteur cérébrale marchant; de l'annonce du handicap à la prise en charge de l'adulte. Monographie de la SoFOP [The walking cerebral palsy; from the announcement of the disability to the care of the adult]. Montpellier, Sauramps Médical, 2005, 252 p. (in French)

17. Damiano D.L., Alter K.E., Chambers H. New clinical and research trends in lower extremity management for ambulatory children with cerebral palsy. Phys. Med. Rehabil. Clin. N. Am., 2009, vol. 20, no. 3, pp. 469-491. DOI: 10.1016/j.pmr.2009.04.005.

18. Lebarbier P., Penneçot G.-F. L'infirmité motrice d'origine cérébrale (IMOC) [Cerebral palsy]. Rev. Chir. Orthop. Traumatol., 2006, vol. 92, no. 4, pp. 393-395. (in French)

19. Grogan D.P., Lundy M.S., Ogden J.A. A method for early postoperative mobilization of the cerebral palsy patient using a removable abduction bar. J. Pediatr. Orthop., 1987, vol. 7, no. 3, pp. 338-340. DOI: 10.1097/01241398-198705000-00019.

20. Nene A.V., Evans G.A., Patrick J.H. Simultaneous multiple operations for spastic diplegia. Outcome and functional assessment of walking in 18 patients. J. Bone Joint Surg. Br., 1993, vol. 75, no. 3, pp. 488-494. DOI: 10.1302/0301-620X.75B3.8496229.

21. DeLuca P.A. The musculoskeletal management of children with cerebral palsy. Pediatr. Clin. North Am., 1996, vol. 43, no. 5, pp. 1135-1150. DOI: $10.1016 / \mathrm{s} 0031-3955(05) 70454-5$.

22. Fabry G., Liu X.C., Molenaers G. Gait pattern in patients with spastic diplegic cerebral palsy who underwent staged operations. J. Pediatr. Orthop. B, 1999, vol. 8, no. 1, pp. 33-38.

23. Sutherland D.H., Davids J.R. Common gait abnormalities of the knee in cerebral palsy. Clin. Orthop. Relat. Res., 1993, no. 288, pp. 139-147.

24. Gage J.R., DeLuca P.A., Renshaw T.S. Gait analysis: principle and applications with emphasis on its use in cerebral palsy. Instr. Course Lect., 1996, vol. 45, pp. 491-507.

25. Rodda J.M., Graham H.K., Carson L., Galea M.P., Wolfe R. Sagittal gait patterns in spastic diplegia. J. Bone Joint Surg. Br., 2004, vol. 86, no. 2, pp. 251-258. DOI: 10.1302/0301-620x.86b2.13878.

26. Nieuwenhuys A., Õunpuu S., Van Campenhout A., Theologis T., De Cat J., Stout J., Molenaers G., De Laet T., Desloovere K. Identification of joint patterns during gait in children with cerebral palsy: a Delphi consensus study. Dev. Med. Child. Neurol., 2016, vol. 58, no. 3, pp. 306-313. DOI: $10.1111 /$ dmcn.12892.

27. Stott N.S., Atherton W.G., Mackey A.H., Galley I.J., Nicol R.O., Walsh S.J. The reliability and validity of assessment of sagittal plane deviations in children who have spastic diplegia. Arch. Phys. Med. Rehabil., 2005, vol. 86, no. 12, pp. 2337-2341. DOI: 10.1016/j.apmr.2005.06.021.

28. Dobson F., Morris M.E., Baker R., Wolfe R., Graham H. Clinician agreement on gait pattern ratings in children with spastic hemiplegia. Dev. Med. Child. Neurol., 2006, vol. 48, no. 6, pp. 429-435. DOI: 10.1017/S0012162206000946.

29. Nieuwenhuys A., Papageorgiou E., Molenaers G., Monari D., De Laet T., Desloovere K. Inter- and intrarater clinician agreement on joint motion patterns during gait in children with cerebral palsy. Dev. Med. Child. Neurol., 2017, vol. 59, no. 7, pp. 750-755. DOI: 10.1111/dmcn.13404.

30. Chibirov G.M., Dolganova T.I., Dolganov D.V., Popkov D.A. Analiz prichin patologicheskikh patternov kinematicheskogo lokomotornogo profilia po dannym kompiuternogo analiza pokhodki u detei so spasticheskimi formami DTsP [Analysis of the causes of pathological patterns of the kinematic locomotor profile based on the findings of computer gait analysis in children with spastic CP types]. Genij Ortopedii, 2019, vol. 25, no. 4, pp. 493-500.

31. Moissenet F., Armand S. Qualitative and quantitative methods of assessing gait disorders. In: Canavese F., Deslandes J. Orthopedic management of children with cerebral palsy: A comprehensive approach. New York, Nova Science Publishers, 2015, pp. 215-239. https://archive-ouverte.unige. ch/unige: 81178 .

32. Õunpuu S., Solomito M., Bell K., DeLuca P., Pierz K. Long-term outcomes after multilevel surgery including rectus femoris, hamstring and gastrocnemius procedures in children with cerebral palsy. Gait Posture, 2015, vol. 42, no. 3, pp. 365-372. DOI: 10.1016/j.gaitpost.2015.07.003.

33. Kuchen D.B., Eichelberger P., Baur H., Rutz E. Long-term follow-up after patellar tendon shortening for flexed knee gait in bilateral spastic cerebral palsy. Gait Posture, 2020, vol. 81, pp. 85-90. DOI: 10.1016/j.gaitpost.2020.07.003.

34. Visscher R., Hasler N., Freslier M., Singh N.B., Taylor W.R., Brunner R., Rutz E. Long-term follow-up after multilevel surgery in cerebral palsy. Arch. Orthop. Trauma Surg., 2021. DOI: 10.1007/s00402-021-03797-0. Online ahead of print.

35. Theologis T. Lever arm dysfunction in cerebral palsy gait. J. Child. Orthop., 2013, vol. 7, no. 5, pp. 379-382. DOI: 10.1007/s11832-013-0510-y.

36. Ławniczak D., Jóźwiak M., Manikowska F. Ocena całkowitej predkości liniowej i katowej stawu kolanowego u chorych z postacia spastyczna mózgowego porazenia po operacyjnym leczeniu tzw. "deformacji dźwigniowozaleznych" kończyn dolnych--badanie prospektywne [Assessment of absolute knee joint linear and angular velocity in patients with spastic cerebral palsy after operative treatment of lever arm dysfunction deformities prospective study]. Chir. Narzadow Ruchu Ortop. Pol., 2010, vol. 75, no. 2, pp. 92-97. (in Polish) 
37. Gannotti M.E., Gorton G.E. 3rd, Nahorniak M.T., Masso P.D. Walking abilities of young adults with cerebral palsy: changes after multilevel surgery and adolescence. Gait Posture, 2010, vol. 32, no. 1, pp. 46-52. DOI: 10.1016/j.gaitpost.2010.03.002.

38. Opheim A., McGinley J.L., Olsson E., Stanghelle J.K., Jahnsen R. Walking deterioration and gait analysis in adults with spastic bilateral cerebral palsy. Gait Posture, 2013, vol. 37, no. 2, pp. 165-171. DOI: 10.1016/j.gaitpost.2012.06.032.

39. Rutz E., Tirosh O., Thomason P., Barg A., Graham H.K. Stability of the Gross Motor Function Classification System after single-event multilevel surgery in children with cerebral palsy. Dev. Med. Child. Neurol., 2012, vol. 54, no. 12, pp. 1109-1113. DOI: 10.1111/dmcn.12011.

40. Lee S.Y., Kwon S.S., Chung C.Y., Lee K.M., Choi Y., Kim T.G., Shin W.C., Choi I.H., Cho T.J., Yoo W.J., Park M.S. Rectus femoris transfer in cerebral palsy patients with stiff knee gait. Gait Posture, 2014, vol. 40, no. 1, pp. 76-81. DOI: 10.1016/j.gaitpost.2014.02.013.

41. Lehtonen K., Mäenpää H., Piirainen A. Does single-event multilevel surgery enhance physical functioning in the real-life environment in children and adolescents with cerebral palsy (CP)?: patient perceptions five years after surgery. Gait Posture, 2015, vol. 41, no. 2, pp. 448-453. DOI: 10.1016/j. gaitpost.2014.11.005.

42. Lopez D., Martel D., Renolleau M. La rééducation et les soins infirmiers postopératoires immédiats (après chirurgie orthopédique multisite). In: Penneçot C.F. Marche pathologique de l'enfant paralysé cérébral [Pathological gait of a child with cerebral palsy]. Montpellier, Sauramps Medica, 2009. (in French)

43. Adolfsen S.E., Ounpuu S., Bell K.J., DeLuca P.A. Kinematic and kinetic outcomes after identical multilevel soft tissue surgery in children with cerebral palsy. J. Pediatr. Orthop., 2007, vol. 27, no. 6, pp. 658-667. DOI: 10.1097/BPO.0b013e3180dca114.

44. Bernthal N.M., Gamradt S.C., Kay R.M., Wren T.A., Cuomo A.V., Reid J., Bales J., Otsuka N.Y. Static and dynamic gait parameters before and after multilevel soft tissue surgery in ambulating children with cerebral palsy. J. Pediatr. Orthop., 2010, vol. 30, no. 2, pp. 174-179. DOI: 10.1097/ BPO.0b013e3181d04fb5.

45. Chibirov G.M., Pliev M.K., Popkov D.A. A new technique of flexor carpi ulnaris transfer in multilevel surgery for upper extremity deformities in spastic cerebral palsy. Med. Glas. (Zenica), 2021, vol. 18, no. 1, pp. 202-207. DOI: 10.17392/1313-21.

46. Rose S.A., DeLuca P.A., Davis R.B. 3rd, Ounpuu S., Gage J.R. Kinematic and kinetic evaluation of the ankle after lengthening of the gastrocnemius fascia in children with cerebral palsy. J. Pediatr. Orthop., 1993, vol. 13, no. 6, pp. 727-732. DOI: 10.1097/01241398-199311000-00007.

47. Seniorou M., Thompson N., Harrington M., Theologis T. Recovery of muscle strength following multi-level orthopaedic surgery in diplegic cerebral palsy. Gait Posture, 2007, vol. 26, no. 4, pp. 475-481. DOI: 10.1016/j.gaitpost.2007.07.008.

48. De Coulon G., Turcot K., Canavese F., Dayer R., Kaelin A., Ceroni D. Talonavicular arthrodesis for the treatment of neurological flat foot deformity in pediatric patients: clinical and radiographic evaluation of 29 feet. J. Pediatr. Orthop., 2011, vol. 31, no. 5, pp. 557-563. DOI: 10.1097/ BPO.0b013e31821fffa0.

49. Popkov D.A., Journeau P., Popkov A.V. Comparative study on results of reconstructive surgery in 45 hip joints of 25 children with cerebral palsy. Eur. Orthop. Traumatol., 2014, vol. 5, no. 1, pp. 57-63.

50. De Moraes Barros Fucs P.M., Svartman C., de Assumpção R.M., Yamada H.H., Simis S.D. Surgical technique: Medial column arthrodesis in rigid spastic planovalgus feet. Clin. Orthop. Relat. Res., 2012, vol. 470, no. 5, pp. 1334-1343. DOI: 10.1007/s11999-011-2185-3.

51. Aroojis A., Patel M., Shah A., Sarathy K., Vaidya S., Mehta R. Indian J. Orthop., 2019, vol. 53, no. 1, pp. 45-52. DOI: 10.4103/ortho.IJOrtho_410_17.

52. Lee H.J., Oh C.W., Song K.S., Kim J.W., Jung J.W., Park B.C., Kim J.Y. Rotational osteotomy with submuscular plating in skeletally immature patients with cerebral palsy. J. Orthop. Sci., 2013, vol. 18, no. 4, pp. 557-562. DOI: 10.1007/s00776-013-0384-3.

53. Funk J.F., Seidl T., Perka C., Haas N.P., Placzek R. Winkelstabile Implantate zur Osteosynthese nach Korrekturosteotomien in der Kinder- und Neuroorthopädie [Locking plates for osteosyntheses of corrective osteotomies in paediatric orthopaedic and neuroorthopaedic patients]. Z. Orthop. Unfall., 2011, vol. 149, no. 4, pp. 428-435. (in German) DOI: 10.1055/s-0030-1270964.

54. Rutz E., Gaston M.S., Camathias C., Brunner R. Distal femoral osteotomy using the LCP pediatric condylar 90-degree plate in patients with neuromuscular disorders. J. Pediatr. Orthop., 2012, vol. 32, no. 3, pp. 295-300. DOI: 10.1097/BPO.0b013e31824b29d7.

55. Kondratek M., McCollum H., Garland A. Long-term physical therapy management following a single-event multiple level surgery. Pediatr. Phys. Ther., 2010, vol. 22, no. 4, pp. 427-438. DOI: 10.1097/PEP.0b013e3181f93cae.

56. Akerstedt A., Risto O., Odman P., Oberg B. Evaluation of single event multilevel surgery and rehabilitation in children and youth with cerebral palsy - A 2-year follow-up study. Disabil. Rehabil., 2010, vol. 32, no. 7, pp. 530-539. DOI: 10.3109/09638280903180171.

57. Patikas D., Wolf S.I., Mund K., Armbrust P., Schuster W., Döderlein L. Effects of a postoperative strength-training program on the walking ability of children with cerebral palsy: a randomized controlled trial. Arch. Phys. Med. Rehabil., 2006, vol. 87, no. 5, pp. 619-626. DOI: 10.1016/j. apmr.2006.01.023.

58. Patikas D., Wolf S.I., Armbrust P., Mund K., Schuster W., Dreher T., Döderlein L. Effects of a postoperative resistive exercise program on the knee extension and flexion torque in children with cerebral palsy: a randomized clinical trial. Arch. Phys. Med. Rehabil., 2006, vol. 87, no. 9, pp. 11611169. DOI: 10.1016/j.apmr.2006.05.014

59. Høiness P.R., Capjon H., Lofterød B. Pain and rehabilitation problems after single-event multilevel surgery including bony foot surgery in cerebral palsy. A series of 7 children. Acta Orthop., 2014, vol. 85, no. 6, pp. 646-651. DOI: 10.3109/17453674.2014.960141.

60. Popkov D.A., Zmanovskaia V.A., Gubina E.B., Leonchuk S.S., Butorina M.N., Pavlova O.L. Rezultaty mnogourovnevykh odnomomentnykh ortopedicheskikh operatsii i rannei reabilitatsii v komplekse s botulinoterapiei u patsientov so spasticheskimi formami tserebralnogo paralicha [Results of multilevel one-time orthopedic surgeries and early rehabilitation combined with botulinum therapy in patients with spastic forms of cerebral palsy]. Zhurnal Nevrologii i Psikhiatrii im. S.S. Korsakova, 2015, vol. 115, no. 4, pp. 41-48. (in Russian)

61. Howard M., Bickley C., Linton J., Northcutt L., Lux M., Scott A., Stephenson L., Barnes D. Early Mobilization Rehabilitation Program for Children with Cerebral Palsy Undergoing Single-Event Multilevel Surgery. Pediatr. Phys. Ther., 2020, vol. 32, no. 3, pp. 218-224. DOI: 10.1097/ PEP.0000000000000709.

62. Thomason P., Baker R., Dodd K., Taylor N., Selber P., Wolfe R., Graham H.K. Single-event multilevel surgery in children with spastic diplegia: a pilot randomized controlled trial. J. Bone Joint Surg. Am., 2011, vol. 93, no. 5, pp. 451-460. DOI: 10.2106/JBJS.J.00410.

63. Harvey A., Rosenbaum P., Hanna S., Yousefi-Nooraie R., Graham K.H. Longitudinal changes in mobility following single-event multilevel surgery in ambulatory children with cerebral palsy. J. Rehabil. Med., 2012, vol. 44, no. 2, pp. 137-143. DOI: 10.2340/16501977-0916.

64. Haumont T., Church C., Hager S., Cornes M.J., Poljak D., Lennon N., Henley J., Taylor D., Niiler T., Miller F. Flexed-knee gait in children with cerebral palsy: a 10-year follow-up study. J. Child. Orthop., 2013, vol. 7, no. 5, pp. 435-443. DOI: 10.1007/s11832-013-0505-8.

65. Dreher T., Thomason P., Švehlík M., Döderlein L., Wolf S.I., Putz C., Uehlein O., Chia K., Steinwender G., Sangeux M., Graham H.K. Long-term development of gait after multilevel surgery in children with cerebral palsy: a multicentre cohort study. Dev. Med. Child. Neurol., 2018, vol. 60, no. 1 , pp. 88-93. DOI: $10.1111 / \mathrm{dmcn} .13618$.

66. Edwards T.A., Prescott R.J., Stebbins J., Wright J., Theologis T. What is the functional mobility and quality of life in patients with cerebral palsy following single-event multilevel surgery? J. Child. Orthop., 2020, vol. 14, no. 2, pp. 139-144. DOI: 10.1302/1863-2548.14.190148.

67. Pilloni G., Pau M., Costici F., Condoluci C., Galli M. Use of 3D gait analysis as predictor of Achilles tendon lengthening surgery outcomes in children with cerebral palsy. Eur. J. Phys. Rehabil. Med., 2019, vol. 55, no. 2, pp. 250-257. DOI: 10.23736/S1973-9087.18.05326-1.

68. Amen J., El-Gebeily M., El-Mikkawy D.M., Yousry A.H., El-Sobky T.A. Single-event multilevel surgery for crouching cerebral palsy children: Correlations with quality of life and functional mobility. J. Musculoskelet. Surg. Res., 2018, vol. 2, pp. 148-155.

69. Shore B.J., White N., Graham H.K. Surgical correction of equinus deformity in children with cerebral palsy: a systematic review. J. Child. Orthop., 2010, vol. 4, no. 4, pp. 277-290. DOI: 10.1007/s11832-010-0268-4.

70. Borton D.C., Walker K., Pirpiris M., Nattrass G.R., Graham H.K. Isolated calf lengthening in cerebral palsy. Outcome analysis of risk factors. J. Bone Joint Surg. Br., 2001, vol. 83, no. 3, pp. 364-370. DOI: 10.1302/0301-620x.83b3.10827.

71. Dietz F.R., Albright J.C., Dolan L. Medium-term follow-up of Achilles tendon lengthening in the treatment of ankle equinus in cerebral palsy. Iowa Orthop. J., 2006, vol. 26, pp. 27-32. 
72. Segal L.S., Thomas S.E., Mazur J.M., Mauterer M. Calcaneal gait in spastic diplegia after heel cord lengthening: a study with gait analysis. J. Pediatr. Orthop., 1989, vol. 9, no. 6, pp. 697-701. DOI: 10.1097/01241398-198911000-00013.

73. Dolganova T.I., Gatamov O.I., Chibirov G.M., Dolganov D.V., Popkov D.A. Kliniko-biomekhanicheskie rezultaty mnogourovnevykh ortopedicheskikh vmeshatelstv pri crouch gait [Clinical and biomechanical results of multilevel orthopaedic interventions in crouch-gait patients]. Genij Ortopedii, 2020, vol. 26, no. 3, pp. 325-333.

74. Gómez-Andrés D., Pulido-Valdeolivas I., Martín-Gonzalo J.A., López-López J., Martínez-Caballero I., Gómez-Barrena E., Rausell E. Evaluación externa de los cambios funcionales y la marcha tras una sesión de miofibrotomía múltiple en escolares con diplejía espástica [External evaluation of gait and functional changes after a single-session multiple myofibrotenotomy in school-aged children with spastic diplegia]. Rev. Neurol., 2014, vol. 58, no. 6, pp. 247-254. (in Spanish)

75. Shishov S.V., Ivshin V.G. Minimalno invazivnye operatsii na myshtsakh u detei s DTsP. Opyt piatiletnego primeneniia [Minimally invasive muscle surgeries in children with cerebral palsy. Experience of five-year use]. Vestnik Novykh Meditsinskikh Tekhnologii. Elektronnyi zhurnal, 2016, no. 2, pp. 137-141. (in Russian)

76. Patthanacharoenphon C., Maples D.L., Saad C., Forness M.J., Halanski M.A. The effects of patellar tendon advancement on the immature proximal tibia. J. Child. Orthop., 2013, vol. 7, no. 2, pp. 139-146. DOI: 10.1007/s11832-012-0480-5.

77. Hachache B., Eid T., Ghosn E., Sebaaly A., Kharrat K., Ghanem I. Is percutaneous proximal gracilis tenotomy as effective and safe as the open procedure? J. Child. Orthop., 2015, vol. 9, no. 6, pp. 477-481. DOI: 10.1007/s11832-015-0699-z.

78. Mansour T., Derienne J., Daher M., Sarraf D., Zoghbi Y., Ghanem I. Is percutaneous medial hamstring myofascial lengthening as anatomically effective and safe as the open procedure? J. Child. Orthop., 2017, vol. 11, no. 1, pp. 15-19. DOI: 10.1302/1863-2548-11-160175.

79. 1. 11, № 1. P. 15-19.

Received: 15.04 .2021

\section{Information about the authors:}

1. Dmitry A. Popkov, M.D., Ph.D., Professor of RAS, correspondent member French Academy of Medical Sciences, Ilizarov National Medical Research Centre for Traumatology and Orthopedics, Kurgan, Russian Federation, ORCID: 0000-0002-8996-867X,

Email: dpopkov@mail.ru

2. Georgy M. Chibirov, M.D., Ph.D., Ilizarov National Medical Research Centre for Traumatology and Orthopedics, Kurgan, Russian Federation, Email: georgii_chibirov@mail.ru

3. Vadim V. Kozhevnikov, M.D., Ph.D.,

Federal Center for Traumatology, Orthopedics and Endoprosthetics, Barnaul, , Russian Federation

4. Nikita S. Gvozdev,

Ilizarov National Medical Research Centre for Traumatology and Orthopedics, Kurgan, Russian Federation, Email: gvozdev_n.s@mail.ru 